\title{
Generation of a multi-antigen-directed immune response for durable control of acute lymphoblastic leukemia
}

S Jo, JH Lee, JJ Mattei, DM Barrett, P van den Elzen, SA Grupp, GSD Reid and AE Seif

Leukemia (2018) 32, 574; doi:10.1038/leu.2017.312; published online 5 January 2018

Correction to: Leukemia (2018) 32, 539-542; doi:10.1038/ leu.2017.290; published online 10 October 2017

Since the publication of this article, the authors have identified an omission in their paper, namely a contributing author was not included in the author list:

$P$ van den Elzen ${ }^{4}$
${ }^{4}$ Department of Pediatrics, University of British Columbia, Vancouver, British Columbia, Canada.

The full and correct author listing is reproduced above. This error has now been rectified and the corrected article appears in this issue together with this corrigendum.

The authors would like to apologise for any inconvenience this may have caused.

\section{OPEN}

\section{Proteomic analysis of JAK2V617F-induced changes identifies potential new combinatorial therapeutic approaches}

S Pearson, AJK Williamson, R Blance, TCP Somervaille, S Taylor, N Azadbakht, AD Whetton and A Pierce

LeukemiaLeukemia (2018) 32, 574; doi:10.1038/leu.2017.333; published online 19 December 2017

Correction to: Leukemia (2017) 31, 2717-2725; doi:10.1038/leu. 2017.143; published online 23 May 2017

This article was originally published under a CC BY-NC-ND 4.0 license, but has now been made available under a CC BY 4.0 license. The PDF and HTML versions of the paper have been modified accordingly. (c) (i) This work is licensed under a Creative Commons Attribution 4.0 International License. The images or other third party material in this article are included in the article's Creative Commons license, unless indicated otherwise in the credit line; if the material is not included under the Creative Commons license, users will need to obtain permission from the license holder to reproduce the material. To view a copy of this license, visit http://creativecommons.org/licenses/ by/4.0/

(c) The Author(s) 2018] 